\author{
А. Молнар \\ Дебреценский Университет, Институт славистики \\ (Венгрия, г. Дебрецен) \\ manja@t-online.hu
}

\title{
СЕМАНТИЧЕСКИЕ ИННОВАЦИИ В ИДИОСТИЛЕ ВЕНЕДИКТА ЕРОФЕЕВА
}

Статья посвящена вопросам неологии Венедикта Ерофеева, творчество которого отличается подчеркнуто раздробленным языком и лексическими нововведениями. В рамках разбора перечисляются разновидности новых слов, способы их образования и употребления в поэтическом тексте «Записки психопата». Исследуются и переосмысления существовавших до этого выражений и явлений языка литературы. Наш подход основывается на трудах таких выдающихся лингвистов, как А.А. Потебня, В.В. Виноградов, Г. О. Винокур и В. П. Григорьев. Анализ способов и форм отражения инноваций, проведенный на этом материале, позволяет сделать выводы о возможностях пополнения лексикона русского языка его собственными и заимствованными ресурсами. Звукобуквенный повтор «р» становится индексом как разговорного или «пьяного» словоплетения, так и литературности. В дополнение к этому отметим, что наблюдаемые заимствования иностранных слов и англицизмов в составе неологизмов в силу их функции передачи экспрессивности и «культовости», а также обнажения штампов, как воспроизводят типичные приемы начала XX века, так и предвещают характерную тенденцию в узуальном употреблении слов русского языка начала XXI века. Таким образом, у Ерофеева манифестируется связь между изрыганием и словом-блудом как формой освоения классической и модернистской литературы.

Ключевые слова: «Записки психопата», словотворчество, звуковая оболочка, извержение, сумасшествие.

Новообразования в тексте «Записок психопата» Венедикта Ерофеева рассматриваются нами в аспекте языковой игры. Семантические преобразования активизируют многоуровневые текстовые структуры, так как неологизмы могут появляться на фоническом и стилистическом уровнях языка. В выработке элементарной классификации мы учитываем вклад индивидуально-авторского слова, вложенный в смыслопорождение художественного текста. 


\section{Словотво-р-p-р-чество:}

1. Самым наглядным примером новаторства в произведении Ерофеева является дублирование согласных и искажение гласных в словах. Пьяный бред становится одной из мотиваций неграмотного написания слов («Сажрем этику!») и постоянного нарушения пристойности выражений ради брани полового содержания и агрессивного мата. Приведем, например, запись от 17 октября. В ней высмеивается остроумная фраза Антонины Григорьевны. Физиологические акты в лозунгах, напоминающих социалистические, служат снижению и разрушению этики, эстетики литературного языка, а также устранению словесных табу, что впоследствии приводит к образованию нового, ерофеевского языка. А «остроумное» слово развивается в «Бр-ред сивой кобылы» [Ерофеев 2011: 6] — во ржание над ним со стороны говорящего. Слово разламывается, «р» повторяется: «бр-ред», и его значение повторяется на уровне знаков.

Слово «сумасшедшего» аутсайдера оргиастическим потоком смывает не только слово правильных людей, но и все идеологизмы, каноны и барьеры. Об этом свидетельствует и воспоминание автора дневника о якобы действительных сочинительских играх в Кировске. Политические возгласы «Брросим!», «Не надо норм!» здесь сливаются с литературными «Рифма и ритм обязательно!!» [Ерофеев 2011: 6]. Звуковой повтор «р» соединяет эти слова. Несоблюдение норм в глазах представителей общества развнозначно «кретинизму». Это уравнение придает новый смысл сумасшествию как форме персонализации поиска нового слова. Ерофеев в тексте создает блестящее стихотворение, в котором известный способ превращения К.Бальмонтом прилагательных в существительные и синестезия получают особую ценность (см. «напрасность прекрасного», «Только звуки желанного / Море смутно-прекрасное» [Ерофеев 2011: 8]). В результате стилизация превращается в пародию, которая строится на ритмообразующих повторениях слов («Дева страстно желанная. / Дева смутно-прекрасная» [Ерофеев 2011: 9]). В данном случае выражение слушателями своего восхищения отражается в подчеркнутом умножении «р»: «Бррраво!». Режущее «р» реализуется в другом стихотворении, имитирующем декадентскую и вместе с тем деревенскую поэзию. У Ерофеева природную тишину нарушает убийство: «Кого-то режут!». Мотив стихотворения «зарезать» развертывается и в желании героя убить любимую, однако романтическая шаблонность такого действия разоблачается.

Итак, под воздействием созвучия сближаются различные слова, представляя центральную тему «Записок», независимо от того, произносит ли их главный герой, либо кто-нибудь другой: «Пррекрасная пародия, чорт побери!» [Ерофеев 2011: 10]. К данной фразе примыкает и замена «Мур» на «Муз» и обратно. Это соотношение словесной игры повторяется и в конце произведения Ерофеева, образуя рамку. Более того, в нелитературном «чоррт побери», с которого и начинается сам текст «Записок», наблюдается установка не только на выражение устной речи, особое произношение пьяного человека, но также и на воспроизведение любимого гоголевского сказа, сулящего черта, в том числе и в «Записках сумасшедшего». 
У Ерофеева дублируются согласные и в следующих словах: «ччорт», «дьявол», «граждане», «оббострренно», «великий наш наррод - строитель». Это позволяет сделать вывод о том, что эти слова взаимосвязаны в смысловом универсуме текста. Ненависть к политическому строю, страсть к Музыкантовой, пьяный бред и сумасшедший смех ставятся в один ряд. Кроме того, игра с литературными цитатами, например, из цветаевского «Пожалей», тоже переходит в «кретинизм»: см. «Крррретин!». Умножение согласных достигает своего пика и в синониме этого слова: «пппсихоппат». Отметим, что в результате звукового повтора намечается и потенциальная связь с образом «похабника» и похабной речью. Собачий язык «огрызания» также становится предметом обсуждения, что может быть отголоском претекста - «Записок сумасшедшего», в котором собаки общаются на человеческом языке. И все это вперемешку у Ерофеева получает название «галиматья». Бредовая речь позволяет и словотворчество, как например, «эргизм» (см. «итожить»). Важность звука «р», как и выражений рычания, рыгания и мороза подтверждает и краткая запись от 18 февраля, состоящая из одних «р».

2. В этом произведении, как и последующих его произведениях, Ерофеев создает слова по аналогии с коммунистическими наименованиями и сокращениями, к примеру, «молчел» - молодой человек. Такой «советский» способ образования слов также подвергается критике.

3. Отдельный уровень ерофеевского языка составляет смешение в одной фразе разных стилевых пластов и лексики разного уровня: «пронзил взглядом ее перси» [Ерофеев 2011: 52], «она все поняла и поспешила обвертикалиться» [Ерофеев 2011: 53]. Ерофеев также сближает разнородные политические события и литературные чтения («туманное восприятие мира» и образ Насера и Имре Надя).

4. В «Записках» Ерофеева употребляются и словесные игры, основанные на соединении слов в непрерывном потоке их устного произношения. Из подобных сочетаний письменных знаков выделяются новые слова или индексы. Женские имена образуются из актов «извергания» слов и сплошного физиологизма: «в мИР Материализма», «изрыГАЛ И НАпивался снова». Возможно, на Музыкантову указывает аббревиатура: «наМ.А.Г.ичен», а на другую женщину — «С.Л.А.бел» [Ерофеев 2011: 48]. На уровне предмета высказывания Ерофеев связывает свое отчисление из институтов и любовный провал с разоблачением коммунистической пропаганды.

5. Характерным для Ерофеева приемом становится также сплетение заимствованных иностранных и русских слов, например, «Mesdames и Господа!» или «Monsieur Rassudock». Последнее слово развивается в произведении в отдельную тему разума. В этой связи также приводится неологизм, созданный путем трансформации заимствованного существительного в русский глагол: «все произнесенное мне импонировало, унисонило» [Ерофеев 2011: 35].

Нагромождаются новообразования и по следующему принципу. Приводятся англоязычные слова без транскрипции и с усечением их суффиксов: «нечего inform», а также наблюдается транскрипция русских слов на английский: «laska и едакая», и наряду с этим, скрещивание русской и иноязычной орфографии: 
«wertik-ом». Слова искажаются их устным произношением, которое может быть и пьяное, но может быть деформировано и на иностранный лад: «Пи-и-ить, ттэк вэшшу ммэть!!!» [Ерофеев 2011: 46]. Приведем другой пример. Немецкое слово, означающее «противление», подвергается перестройке во время его выучивания, употребления и повторения: «энт-гегент-рэтен» [Ерофеев 2011: 88].

В стиховой записи от 22 декабря развертываются новые формы заимствованного слова «сентимент». Субъект речи отрицает чувствительность, сопровождающую любовь, и разумеется, сам язык чувств: «Извращенно сентиментальничать», «Я не пытался сенсинировать!». Герой отказывается и быть братом любимой женщины, т. е. отрицать чувственные стороны любви: «И все-таки я отказался брудировать!» [Ерофеев 2011: 47]. «Обрусизация» иностранных слов придает мнимую изощренность речи, словно возвышая ее низкий предмет. Первая нежная любовь и измена стоят рядом с половым актом и мордобоем. Как и все идеологические и литературные -измы, так и романтизм отрицается и снижается до уровня «отеллирования», понятия, опять же являющегося нововведением Ерофеева. Водевильное представление любовной истории превращается в порождение нового слова: «опереттично» - с подчеркнутым концом отношений и новой, «ирреальной» игрой слов и их формой: «sex-appea-ль-ности».

6. Итак, неологизмы Ерофеева обнажают разные способы трансформации иностранных слов. В какой-то мере они становятся воспроизведением словотворческих приемов И. Северянина и будетлян. Об этом свидетельствуют разные зашифрованные и открытые игры слов, цифр и т.д., напоминающие кубофутуристические опыты. Они служат экспериментированию в процессе поиска Ерофеевым своего слова. Нельзя объяснять такие игры, как слова лесенкой («припп / ппом / мню»), ошибки в формировании слов («обруазеpll и ЛЕ»), неологизмы («Домай!», «бардуав») или повтор частицы «КРИ» просто пьяным бредом, словесной маской алкоголика. Если попытаться узреть в этой бессмыслице какую-нибудь закономерность, то, как и в случае заумного языка, можно обнаружить ее на уровне фоники: «до дюж-апр, ВДРУГ дрожь и — в “руамуан...”», «Теперьпопор» [Ерофеев 2011: 67]. Распад слов на их единицы, умножение или лишение букв («все ЛЕ и по совету»), свидетельствует о разложении языка, как особого языка психопата без сглаживания ошибок, без исправления неточностей, в том числе и в цитатах. Вместе с тем здесь наблюдается и критика слога для будущей его перестройки.

7. Матерщина, характерная для текста «Записок» реализуется и в образе матери, что демонстрирует и связь этих слов. Автор дневника Ерофеева не щадит не только свою любимую, но также и собственную мать. По отношению к ней он также позволяет ругательства и пьяное заикание. Сближение образов maman и Музыкантовой становится явным. Дубликация букв отражает эмоциональность устных высказываний: «дьяволу», «Иддиот», «Ссккот».

8. Оперируя разными способами образования слов, Ерофеев прибегает и к искажению смысла. Согласно примечаниям к изданию полного текста «Записок», к примеру, «нелабильный исход» в данном случае следует понимать как «окончательный исход» [Ерофеев 2011: 242]. 8 мая выяснение значения дурака, человека, упавшего 
с луны и пьяного, приводит к тематизации функции слова, разграничения общепринятого значения и нового смысла. Собеседник удивляется тому, что герой «пытается втискивать какое-то другое значение в слово...», например, в «люблю» значение «ненавидеть» [Ерофеев 2011: 157]. Абстрактные, «духовные» слова не могут быть точно определены. В качестве примера приводятся еще «ЦК» и «солнце» / «денатурат», как взаимозаменимые на основании их некоего общего признака. Это становится характерным для необыкновенного ума героя-«грузчика».

9. Порождение метафор также занимает важное место в тексте Ерофеева. Субъект речи охотно образует непривычные, неожиданные словосочетания, слившие иносказательными: «прилив остроумной животности» [Ерофеев 2011: 159]. Точно так же, как и в стихотворениях, проза поэтизируется благодаря повторяющимся выражениям, которые из поэтического вдруг трансформируются и раскрывают вполне конкретный или необычный смысл. Бывает, что застывшие метафоры реализуются, тем самым оживают: например, телесные отношения с грузной Мартыновой описываются так: «не я обнимал необъятное, а необъятное обнимало меня» [Ерофеев 2011: 160].

В произведении Ерофеева с помощью перманентной диалогизации слова раскрывается, какое изменение происходит, когда вещь, обозначенная словом, становится объектом поэтического текста. Прозаическое слово трансформирует символическое выражение в индекс, и слово ориентирует на другое слово, устраняя его словарные и укоренившиеся значения. А это порождает новые знаки и метафоры, вместо сгущения образного слова и фиксации его значения.

Обратим внимание и на коренную метафору словопорождения в тексте Ерофеева. Извержение семени или испражнение кала, рвоты и т. п. оказывается явлением, аналогичным балаболничанию, произнесению слов. В воображаемых или действительных диалогах один из собеседников так и отождествляет женщину с «чувствительным ватерклозетом» [Ерофеев 2011: 33]. Предположительно, это опять же относится прежде всего не к самой любви, а к чувствительному слогу, который следует устранить. Любовный сюжет, репрезентируемый при помощи физиологических выбросов, служит для этой цели путем «изрыгания» слова. Следующие цитаты из текста демонстрируют метафорическое соотношение между изверганием, субъектностью и творчеством: «Из влагалища моего воображением периодические розовые, кричащие Шедевры...» [Ерофеев 2011: 49]. В следующей фразе это дополняется еще и темой погоды: «Я блевал недожеванными кусочками декабря в серенькую урну ноябрьского пессимизма...» [Ерофеев 2011: 48].

В качестве образца Ерофеев мог прибегнуть и к произведениям маркиза де Сада, в которых анальные аналогии и действия героев с калом представляются подобным образом для снятия всяких, в том числе и языковых табу. В то же время вещи, вызывающие отвращение, и их репрезентация, предваряют уже постмодернизм с его пересмотром ценностей, эстетики и этики слова, действий и явлений. Вернемся к началу, к нашей исходной точке: «Э-эттика! Одно слово заставляет меня изрыгать тысячи проклятий по адресу...» - утверждается в «Записках» Ерофеева. Идеологемы также обнажаются и разоблачаются: «я положительно потерял всякое уважение к этому "искалеченному счастьем"» [Ерофеев 2011: 32]. 
Вот как отрицается литература в записи от 13 декабря: «Давайте сообща засирать сокровища мировой поэзии! Ппёрнем! Отравим атмосферу!». Здесь противопоставляются «мы и они», т.е. «психопаты», вырабатывающие новый слог, и приверженцы традиционных ценностей: «Мы - кретины!!», «Ведь вы так чисты!» [Ерофеев 2011: 36]. Классическая поэзия куртуазно преклонялась перед женщинами, Ерофеев же зовет вернуть им физиологические свойства и раскрыть их карнавально, т.е. полностью, со всех сторон. Отвратительное таким образом может обрести значение эстетического. Ерофеев и в этом юродствует, что выражается в искажении им слова: «белая кофточка была вымазана в чем-то отвратительном, мокрое платье слишком неэстетно загнуто...» [Ерофеев 2011: 42]. В рамках постмодернистических переработок литературных образцов (их чтение, проглатывание в форме стилизации и выброс в форме пародии), вводится и политическая актуальность, которая один раз смешивается с обгаживанием кабинета писателя Льва Толстого.

Итак, в нашей статье описывается порождение новых языковых единиц, сочетаний, выделяются новые значения и контекстуальные смыслы. Сумасшествие означает как деконструкцию классического литературного языка, так и разработку нового слова для акцентирования своего присутствия субъектом текста.

\title{
Литература
}

Ерофеев В. В. Записки психопата. (ред., комм. А. Е.Яблоков) М. : Захаров, 2004. $272 \mathrm{c}$.

Виноградов В. В. О языке художественной литературы. М. : Гослитиздат, 1959. $656 \mathrm{c}$.

Винокур Г. О. О языке художественной литературы. М. : Высшая школа, 1991.445 с.

Григорьев В. П. Словотворчество и смежные проблемы языка поэта. М. : Наука, 1986. $254 \mathrm{c}$.

Потебня А. А. Мысль и язык. М. : Лабиринт, 1999. 192 с.

Смирнова Е. Е. Реализация приема ретардации в «Записках психопата» Вен. Ерофеева // Вестник КГУ им. Н. А. Некрасова. 2008. №1. С. 138-139.

\author{
A. Molnar \\ Institute of Slavistics (University of Debrecen) \\ (Hungary, Budapest) \\ manja@t-online.hu
}

\section{SEMANTIC INNOVATIONS IN VENEDIKT EROFEEV'S IDIOSTYLE}

This paper studies the neology of Venedikt Erofeev whose works are distinguished by their pointedly fragmented language and lexical innovations. As part of our analysis we list new varieties of words, ways of their creation and use in «Notes of a Psychopath». 
Reinterpretation of the pre-existing expressions of literary language is also studied. Our approach is based on the writings of such well-known linguists as A. A. Potebnya, V.P. Grigor'ev, G. O. Vinokur, V.V. Vinogradov. The analysis of methods and forms of innovation reflection conducted on this material allows to draw conclusions about the possibilities of replenishing the lexicon of the Russian language with its own and borrowed resources. Phonetic repeat of " $r$ " becomes the index of both colloquial or "drunken" speech as well literariness. In addition, we note that the observed forms of borrowed foreign words and anglicisms in the composition of neologisms due to their functions of shaping expressiveness and «cult» as well as exposing stamps, both reproduce typical techniques of the beginning of the $20^{\text {th }}$ century, and foreshadow a characteristic trend in the usage of the Russian language at the beginning of the $21^{\text {st }}$ century. Thus, Erofeev manifests the relationship between eruption and word-fornication as a form of mastering classical and modernist literature.

Key words: «Notes of a Psychopath», word creation, sonic shell, eruption, madness.

\section{References}

Erofeev V.V. Zapiski psikhopata. [Notes of a Psychopat]. A. E. Yablokov (ed., comment.). Moscow, Zakharov, 2004. 272 p.

Grigor'ev V.P. Slovotvorchestvo i smezhnye problemy yazyka poeta [Word creation and related problems of the poet's language] Moscow, Nauka, 1986. $254 \mathrm{p}$.

Potebnya A.A. Mysl' i yazyk [Thinking and language]. Moscow, Labirint, 1999. $192 \mathrm{p}$.

Smirnova E. E. [Realizatsiya priema retardatsii v «Zapiskakh psikhopata» Ven. Erofeeva [Realisation of retardation method in Ven. Erofeev's Notes of a Psychopat]. Vestnik KGU im. N. A. Nekrasova. 2008, no. 1. pp. 138-139. (In Russ.)

Vinogradov V.V. O yazyke khudozhestvennoy literatury [On the language of literature]. Moscow, Goslitizdat, 1959. 656 p.

Vinokur G. O. O yazyke khudozhestvennoy literatury [On the language of literature]. Moscow, Vysshaya Shkola, 1991. 445 p. 